\title{
Prevalence of Sexually Transmitted Infections in a Tertiary Care Centre
}

\author{
Karn D, Amatya A, Aryal ER, KC S, Timalsina M
}

Department of Dermatology and Venerology

\begin{abstract}
Background

The burden of sexually transmitted infections is huge and is disproportionately affecting developing nations. In Nepal, recent available data on sexually transmitted infections are mostly targeted to high risk population. A prevalence study was thus done to explore the pattern of sexually transmitted infection syndromes among general population of Nepal.
\end{abstract}

Dhulikhel Hospital - Kathamndu University Hospital

Dhulikhel Hospital, Kavre, Nepal

\section{Corresponding Author \\ Dr. Dharmendra Karn \\ Department of Dermatology and Venerology \\ Dhulikhel Hospital - Kathmandu University Hospital} Kavre, Nepal

Email: dddkarn@gmail.com

\section{Citation}

Karn D, Amatya A, Aryal ER, KC S, Timalsina M. Prevalence of Sexually Transmitted Infections in a Tertiary Care Centre. Kathmandu Univ Med J 2011;34(2)44-8.

\section{Objectives}

To highlight the prevalence and changing pattern of sexually transmitted infections among general population.

\section{Methods}

A retrospective study. The study was conducted among 145 patients attending Department of Dermatology and Venerology, Dhulikhel Hospital Kathmandu University Hospital, for voluntary counseling and testing from April 2010 to April 2011. Syndromic case management approach was used for the classification and treatment of the patients.

\section{Results}

106 patients were suffering from Sexually Transmitted Infections and 2 patients were positive for Human Immunodeficiency Virus. The most common diagnosis was genital viral infections (41.7\%). Prevalence was highest among drivers/conductors (26.9\%) and migrating workers (23.1\%). Age group 20 to 24 years was the maximum sufferers (37\%). Unsafe sexual activity (66.7\%) was the most potential exposure and majority of the patients were not consistent in using condom.

\section{Conclusions}

Genital viral infections constitute the major bulk of sexually transmitted infections. Majority of the patients suffering from sexually transmitted infections were in the age group 20 to 24 years and were mostly drivers, conductors or migrating workers by occupation. In the background of few available baseline data, the results are expected to assist successful target interventions in the near future.

\section{KEY WORDS}

prevalance, sexually transmitted infection

\section{INTRODUCTION}

Sexually Transmitted Infections (STIS) is one of the major causes of morbidity and mortality throughout the world. STIs still remain a major public health problem in developing nations and poor economy is considered one of its prime factors. ${ }^{1}$ There are convincing results that the long term complications of STIs are disproportionately borne by women and their children. ${ }^{2}$ People with STIs are at high risk of contracting HIV infection as well.

World Health Organization estimates around 340 million curable STIs each year worldwide with its highest prevalence in South and Southeast Asia. ${ }^{3}$ STIs are extremely underreported, under diagnosed and their sequelae come either under maternal, child or cancer morbidity and mortality statistics. Hence, the exact toll of existing STIs is difficult to make. Various studies in Nepal (Kathmandu, Pokhara and 22 Terai districts) have concluded that STIs are more prevalent among high risk population and there is a low prevalence in general population. ${ }^{4}$ Economic deprivation, low education, social stigmata, socioeconomic inequality and economically driven migration and mobility are the reasons found to be associated with the risk of STI/ HIV infection. ${ }^{5,6}$ 
Available data on STIs are targeted to high risk population as Community Sex Workers (CSWs), intravenous drug abusers, migration workers and truck drivers; a paucity of community based data on STIs was thus felt. Hence the objective of this study is to reveal the prevalence of STIS among general population.

\section{METHODS}

This is a retrospective study conducted in the Department of Dermatology and Venerology, Dhulikhel Hospital Kathmandu University Hospital.

The sample size was 145 patients (104 male, 39 female and 2 transgender7). The study population comprised of all patients who presented to the department directly or were referred by other departments for Voluntary Counseling and Testing (VCT) from April 2010 to April 2011.8 The questionnaire was developed by National Centre for AIDS and STD Control (NCASC), Ministry of Health, Nepal Government for VCT. Patients were interviewed with their consent in private about STI symptoms as urethral discharge, vaginal discharge, genital ulcer, inguinal swelling, dysuria, scrotal swelling and lower abdominal pain.

As there were technical and diagnostic difficulties for the exact isolation of pathogen, classification and treatment of STIs was done as per the Syndromic case management endorsed by WHO/UNAIDS in early 1990s; with addition of genital viral infections and miscellaneous (e.g.: venerophobia) category. ${ }^{10,11}$ Among the total patients $(\mathrm{N}=145)$, variables as gender, occupation, age group, potential risk of exposure and frequency of use of condoms were analyzed.

Data analysis was done with Statistical Package for the Social Sciences (SPSS) version 16. Limited sample pool (145) visiting VCT clinics, limited articles of its kind and difficulty in isolating the exact pathogen were some of our limitations.

\section{RESULTS}

Among the total VCT patients ( $\mathrm{N}=145), 108$ (74.5\%) had STIs, 26 (17.9\%) had HIV/AIDS related symptoms and $11(7.6 \%)$ had no STI. HIV/AIDS related symptoms included symptoms/diseases which had some degree of immunodeficiency but had inadequate evidence to be called HIV or AIDS. 104 male (59 married, 45 unmarried), 39 female (30 married, 9 unmarried) and 2 transgender (Unmarried) were included in this study.

Among the 108 STI cases, $73(53.3 \%)$ were male, 33(22.75\%) were female and 2(1.4\%) were transgender. Table 1 shows the gender wise distribution of major STI syndromes. Genital Viral infection (41.7\%) was the most common diagnosis followed by Genital discharge syndrome (25\%), miscellaneous category (17.6\%) and Genital ulcer syndrome (15.7\%).

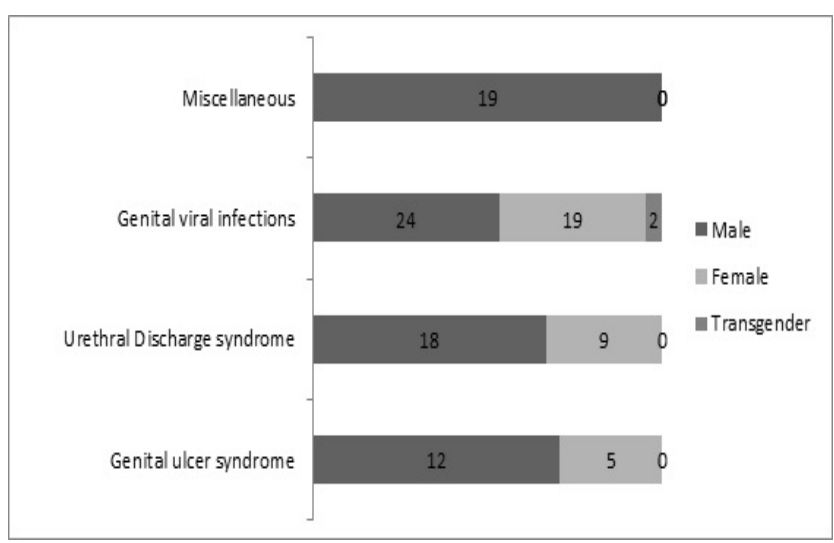

Figure 1. Distribution of STI Syndromes according to gender.

Table 1. Distribution of STI Syndromes in relation to occupation.

\begin{tabular}{lllll} 
& $\begin{array}{l}\text { Genital } \\
\text { ulcer syn- } \\
\text { drome }\end{array}$ & $\begin{array}{l}\text { Urethral } \\
\text { Discharge } \\
\text { syndrome }\end{array}$ & $\begin{array}{l}\text { Genital } \\
\text { viral infec- } \\
\text { tions }\end{array}$ & $\begin{array}{l}\text { Miscella- } \\
\text { neous }\end{array}$ \\
\hline Farmers & 2 & 5 & 0 & 0 \\
\hline Housewives & 1 & 6 & 5 & 0 \\
\hline Job holder & 0 & 3 & 3 & 1 \\
\hline $\begin{array}{l}\text { Drivers/ Con- } \\
\text { ductors }\end{array}$ & 9 & 4 & 14 & 2 \\
\hline $\begin{array}{l}\text { Students } \\
\text { Unemployed }\end{array}$ & 0 & 0 & 5 & 9 \\
\hline $\begin{array}{l}\text { Migrating } \\
\text { workers }\end{array}$ & 0 & 1 & 0 & 3 \\
\hline \begin{tabular}{l} 
Others \\
\hline
\end{tabular} & 5 & 0 & 17 & 0 \\
\hline
\end{tabular}

Table 1 shows the distribution of STIs in relation to occupation. STI was most common among drivers/ conductors (26.85\%). STI was then common among migrating workers $(23.1 \%)$, students $(12 \%)$ and housewives (11.1\%). Majority of the students attending the clinics with STIs were from Kathmandu.

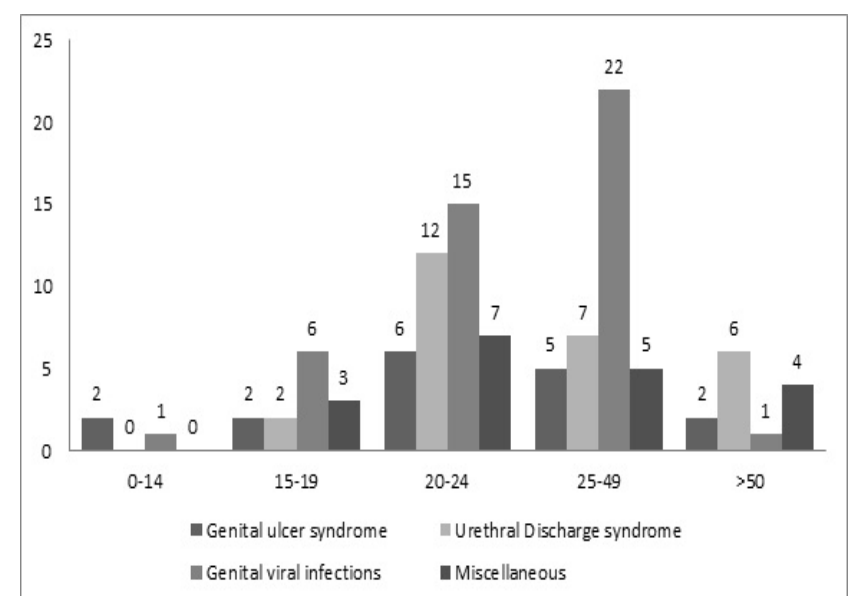

Table 3. Age distribution of patients with STI Syndromes.

Figure 2 represents the STI syndromes according to various age groups. STI was most common in 20-24 years age group. 
Table 2. Most recent potential exposure in patients with STI.

\begin{tabular}{|c|c|c|c|}
\hline Most recent potential exposure & Male & Female & Transgender \\
\hline $\begin{array}{l}\text { Needle stick (Occupational expo- } \\
\text { sure) }\end{array}$ & 0 & 0 & 0 \\
\hline Rape history & 0 & 1 & 0 \\
\hline Sharing injecting equipments & 6 & 0 & 0 \\
\hline Organ/Blood products transfusion & 2 & 3 & 0 \\
\hline Oral sex & 5 & 3 & 0 \\
\hline Anal intercourse & 9 & 5 & 0 \\
\hline Tattoo/Piercing & 0 & 0 & 0 \\
\hline Vertical transmission & 0 & 2 & 0 \\
\hline \multicolumn{4}{|l|}{ Unsafe sexual practices } \\
\hline Heterosexual & 43 & 19 & 0 \\
\hline Homosexual & 3 & 0 & 2 \\
\hline Bisexual & 5 & 0 & 0 \\
\hline
\end{tabular}

Table 2 reveals the gender of STI cases with their most recent potential exposure. Recent unsafe sexual activity (66.7\%) was the most common exposure. Apart from the common heterosexual activity, bisexual and homosexual activity was present in 5 patients each. Patients also had anal intercourse $(17 \%)$, oral intercourse $(7.4 \%)$, sharing injecting instruments (5.55\%) and blood/organ transfusion (4.6\%) as other recent exposures.

Two cases of the 108 STI cases were positive for Human Immunodeficiency Virus (HIV) infection.

Table 5. Frequency of use of condom in last twelve months.

\begin{tabular}{llll|}
$\begin{array}{l}\text { Frequency of } \\
\text { condom use }\end{array}$ & Male & Female & Transgender \\
\hline Never & 12 & 4 & 0 \\
\hline Sometimes & 23 & 15 & 1 \\
Always & 32 & 12 & 0 \\
\hline $\begin{array}{l}\text { Not used } \\
\text { recently }\end{array}$ & 6 & 2 & 1 \\
\hline
\end{tabular}

Table 5 shows the data regarding frequency of condom use among patients with STIs. 44 patients $(40.7 \%)$ used condom regularly, 39 patients (36.1\%) used condoms sometimes only whereas 16 patients ( $14.8 \%$ ) had never used condom.

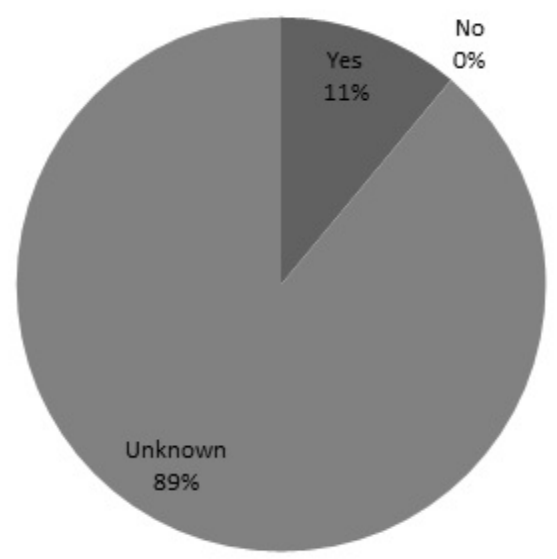

Table 6. Distribution of patients having history of STIs to partner.
Table 6 shows the distribution of patients with a history STIS to the exposed partner. Maximum patients (88.9\%) were unknown about the status of STIs in their partner whereas twelve patients had positive STIs among their partner.

\section{DISCUSSION}

Although the terms STIs and Sexually Transmitted Diseases (STDs) are used synonymously, STIs also includes infections not affecting the genitalia but are transmitted by sexual interaction as Hepatitis B/C, HIV and HTLV-1. ${ }^{12}$ Apart from the risks of STIs, STIs are also an important determinant of increased HIV transmission. ${ }^{7,13-15}$ The exact distribution of STIs is difficult to find however the affected groups are mostly urban residents, unmarried individuals and young adults.

In our study, fewer women visited the clinic than men. This could be due to the stigma or shame and reluctance to mention their problems regarding STIs. Studies conducted in various parts of South East Asia have shown almost double prevalence of STIs among women. ${ }^{16,17,20}$ In developing nations, women have limited access to information or health services than men and they are too busy in household or child caring activities. ${ }^{21-23}$ They have symptoms for longer period and less often they seek treatment than men. Also, where women are economically dependent on men, they have problems even informing the disease to their partner(s) and less often they visit a health centre without a male relative.

Genital viral infection (41.7\%) was the most common diagnosis in our study. Genital herpes was the commonest STI (28.7\%) in the study done by Choudhry S. et al as well. ${ }^{31}$ In the past few decades, Viral STIs are being more common than bacterial STIs. ${ }^{18,19}$ Reason for this increase may be due to the relative decline in bacterial STIs. This may reflect increased condom use, rampant use of antibiotics and asymptomatic bacterial and protozoal STIs, Particularly gonorrhea in men and chlamydia and trichomonas in women. ${ }^{24-26}$

Regarding occupation, drivers/conductors had maximum STI (26.85\%). In the Doti district, male migrants migrate to India working predominantly as truck drivers/helpers. ${ }^{27}$ These migrants had regular brothel visits and condom use was also infrequent. They had an HIV seroprevalence of $10.3 \%$.

Migrating workers also had significant STIs (23.1\%) in our study. In Nepal, international migration to India and abroad has increased by $57 \%$ within a decade. ${ }^{28}$ In Kailali district, women partner of migrants were much more vulnerable to HIV infection than women with non migrant partners. ${ }^{29}$ The overall STI prevalence among women in Kailali district with migrant partners was $30 \%$.

Among migrating men, very few of them reported extramarital sex before travel but extramarital sex was more common after return which appeared due to the 
improved finance and higher social status of the successful migrants. $^{30}$

Highest prevalence was seen among the age group 2024 years (37\%). It contrasts with the study performed by Rao VG. et al., where age group 30-34 was the maximum sufferers. ${ }^{20}$ This contrast is probably because the study included only married individuals and population included in our study may have less knowledge regarding STIs. However our result correlates with the study done by Choudhry S. et al. where the mean age of STI is 24 years. ${ }^{31}$

Recent unsafe sexual activity was the most potential exposure in our study (66.7\%). Unprotected sex with an infected partner is by far the most important risk factor for STI/HIV transmission worldwide. ${ }^{2,32}$ This study is expected to be a help to authorities to formulate appropriate interventions for potentially vulnerable group. However, larger population studies will be required in the near future to explore the further distribution and effectiveness of STI control programs.

\section{CONCLUSION}

The results concluded that the frequency of viral STIs is more and is common among younger population, drivers/conductors and migrating workers. Thus, STI and HIV epidemics need actions to be based on research, multidisciplinary analysis, policy making and appropriate intervention strategies. Similarly, Prompt diagnosis and treatment of curable STIs can quickly interrupt the transmission cycle and hence prevent its dreadful complications.

\section{REFERENCES:}

1. Memish ZA, Osoba AO. International travel and sexually transmitted diseases. Travel Med Infect Dis 2006; 4:86-93.

2. Aral S, Over M, Manhart L, Holmes KK. Sexually transmitted infections. In: Jamison D, Evans D, et al. Disease control priorities in developing countries. Washington D.C, World Bank and Oxford University Press, 2006, pp.311-330.

3. World Health Organization website: Global prevalence and incidence of selected curable sexually transmitted infections overview and estimates. Available at www.who.int/hiv/pub/sti/who_hiv_ aids_2001.02.pdf. Accessed November 22, 2011.

4. UNAIDS website: UNGASS Country Progress Report in Nepal. Available at: http://www.unaids.org/en/dataanalysis/monitoringcountrypr ogress/2010progressreportssubmittedbycountries/nepal_2010_ country_progress_report_en.pdf. Accessed November 222011.

5. Bloom D, River path associates, Sevilla J. Health, wealth, AIDS and poverty. Working paper, 2002. Available at: http://www.adb.org/ documents/reports/health_wealth/hwap.pdf.

6. Bloom D, Mahal A, Rosenberg L, Sevilla L, Steven D, Weston M. Asia's economics and the challenge of AIDS. Manila: Asian Development Bank, 2004.

7. Blanchard JF, Moses S. Female sex workers and their clients in the epidemiology and control of sexually transmitted diseases. In: Holmes KK, editor. Sexually Transmitted Diseases, 4th ed. The McGraw Hill Companies, 2008. pp203-04.

8. World Health Organization website: HIV testing and counseling. Available at http://www.who.int/hiv/topics/vct/en/. Accessed November 22, 2011.

9. NCASC. National guidelines for voluntary HIV/AIDS counseling and testing. Kathmandu: National Centre for AIDS and STI Control: 2007.

10. UNAIDS. The public health approach to STD control: UNAIDS Technical Update. Joint United Nations Program on HIV/AIDS, 1998.

11. WHO. Guidelines for the management of sexually transmitted infections. World Health Organization 2003.

12. Sharma VK. Epidemiology of Sexually Transmitted Diseases. Viva books: 2003. P 14-41.

13. Fleming DT, Wasserheit JN. From epidemiological synergy to public health policy and practice: The contribution of other sexually transmitted diseases to sexual transmission of HIV infection. Sex Transm Infect 1999; 75:3-17.

14. Coombs RW, Reichelderfer PS, Landay AL. Recent observations on HIV type-1 infection in the genital tract of men and women. AIDS 2003; $17: 455-80$
15. Quinn TC, Wawer MJ, Sewankambo N, et. al. Viral load and heterosexual transmission of human immunodeficiency virus type 1. Rakai Project Study Group. N Engl J Med 2000; 342:921-929.

16. Hawkes S, Morison L, Chakraborty J, et al. Reproductive tract infections: prevalence and risk factors in rural Bangladesh. Bull World Health Organ 2002; 80:180-8.

17. Thomas K, Thyagarajan SP, Jeyaseelan L. et al. Community prevalence of sexually transmitted diseases and human immunodeficiency virus infection in Tamilnadu, India: a probability proportional to size cluster survey. Natl Med J India 2002; 15:135-9.

18. O'Farrell N. Increasing prevalence of genital herpes in developing countries: Implications for heterosexual HIV transmission and STI control programmes. Sex Transm Infect 1999; 75:377-84.

19. Ray K, Bala M, Gupta SM, et al.? Changing trends in sexually transmitted infections at a regional STD centre in north India. Indian J Med RES 2006; 124:559-68.

20. Rao VG, Anvikar A.et al. Prevalence of sexually transmitted disease syndromes in tribal population of central india. J Epidemiol Community Health 2009; 63:805-06.

21. Sirirassamee B, Sethaput C, Yoddumnern-Attig B. Gender Perspectives in Reproductive Health Practices in Thailand: A Synthesis of Research Findings. Nakhonpathom, Thailand: Institute for population and social research, Mahidol University, 2003.

22. Dixon-Mueller R. Gender inequalities and reproductive health: Changing priorities in an era of social transformation and globalization. Policy Popul Res Pap 1999; 16:1-29.

23. Voeten H, O'Hara HB, Kusimba J, et al. Gender differences in health care seeking behavior for sexually transmitted diseases. Sex Transm Dis 2004; 31:265-72.

24. Garnett GP, Bowden FJ. Epidemiology and control of curable sexually transmitted diseases: opportunities and problems. Sex Transm Dis 2000; 27:588-99.

25. Kretzschmar M, van Duynhoven Yt, Severijenen AJ. Modeling prevention strategies for gonorrhea and Chlamydia using stochastic network stimulations. Am J Epidemiol 1996; 144:306-317.

26. Bowden FJ, Garnett GP. The epidemiology and control of Trichomonas vaginalis: parameterising and analyzing a mathematical model. Sex Transm Infect 2000; 76:248-256.

27. Poudel KC, Jimba M, Okumura J, Sharma M, Poudel Tandukar K, Wakai S. Migration in the far western Nepal: A time bomb for a future HIV/ AIDS epidemic? Trop Doct 2004; 34: 30-31. 
28. Furber AS, Newell JN, Lubben MM. A systematic review of current knowledge of HIV epidemiology and of sexual behavior in Nepal. Trop Med Int Health 2002; 7:140-148.

29. Singh S, Mills E, Honeyman S, Suvedi BK, Pant NP. HIV in Nepal: Is the violent conflict fuelling the epidemic? PLoS Med 2005; 2:e216.

30. Poudel KC, Okumura J, Sherchand JB, Jimba M, Murakarmi I, Wakai S. Mumbai disease in far western Nepal: HIV infection and syphilis among male migrant -returnees and non migrants. Trop Med Int Health 2003; 8:933-939.

31. Choudhry S, Ramachandran VG, Das S, Bhattcharya SN, Mogha NS. Pattern of sexually transmitted infections and performance of syndromic management against etiological diagnosis in patients attending the sexually transmitted infection clinic of a tertiary care hospital. Indian J Sex Transm Dis 2010; 31:104-08.

32. UNAIDS. AIDS epidemic update: Dec 2005. Geneva: UNAIDS; 2005. 